\title{
Listen and Watch:The Practice of Lecturing and the Epistemological Status of Sex Education Films* in Germany
}

Anja Laukötter

\section{Summary}

This article takes as its starting point Frauennot-Frauenglück (Women's Misery-Women's Happiness), a film representative of health education films on sex hygiene in Weimar Germany. This paper opens by situating the film in the landscape of German health education films from World War I to the Weimar era. I document the evolution of interest in sexual health education films in the early decades of the twentieth century and show how their narratives changed as a result of the increasing popularity of feature films in the Weimar period.

The article then focuses on the lectures which accompanied health education films. I argue that an analysis of these under-investigated lectures can raise new stimulating epistemological questions on the historical status of health education films, as these lectures changed the filmic dispositive. I show how this common practice served as a technique of rhetorical reworking in efforts to adjust or orient the visuality of what was shown to the public. Drawing on two very different lectures which accompanied Frauennot-Frauenglück, the article identifies two approaches to lecturing. While one consisted in enabling controversial films to be screened to the public, the other (socialist) approach transforms initial censorial intentions, allowing the speaker stress his personal or new positions.

Keywords: Sex education, lecture, (filmic) dispositive, censorship, abortion, (film) versions, Germany, Weimar period

* This paper received support from the Excellence Initiative of the University of Strasbourg funded by the French government's Future Investments program. We are grateful for copyediting by Jean-Yves Bart.

Anja Laukötter, Max-Planck-Institute for Human Development, History Department, Lentzeallee 94,14195 Berlin (laukoetter@mpib-berlin.mpg.de) 


\section{Introduction}

On the 21st of March 1930, the health education film Frauennot-Frauenglück (Women's Misery - Women's Happiness) received its world premiere in the Apollo cinema in Zurich, Switzerland. ${ }^{1}$ In subsequent years, FrauennotFrauenglück was shown in various other countries in Europe and beyond. Produced by Lazar Wechsler and directed by Eduard Tissé, an associate of Sergei Eisenstein, the semi-documentary film Frauennot-Frauenglück deals with sex education in a broad sense, giving advice on questions of reproduction, illustrating social and medical problems and consequences arising from (illegal) abortion, showing the joy of childbirth and depicting the medical practice of the caesarean section (see image VI below). ${ }^{2}$ Because of the topics raised and the way it was screened, the film was highly controversial: there were demonstrations to protest it and even strong interventions by Catholic lobby groups and women's organisations in Germany - particularly in the south of the country. The film was censored on several occasions in the following years and youths were no longer permitted to attend screenings. In Germany (and Switzerland), the censorship board demanded that a "scientific lecture" be given before the film was screened. These lectures allowed films like Frauennot-Frauenglück to be shown to a wider public.

Frauennot-Frauenglück is an exceptional case study because it was widely circulated and a variety of versions were screened. From a filmic point of view, the film is representative of health education films of the era. In light of this, this paper will initially situate the film in the landscape of health education films of the Weimar era. ${ }^{3}$ It shows Frauennot-Frauenglück to be emblematic of sex education films of the $1920 \mathrm{~s} / 30 \mathrm{~s}$, as it displays the main features characteristic to sexual health education films.

Secondly, I will analyse two of the lectures which accompanied the film. Although it was common throughout the first half of the twentieth century for the censorship board to request a contextualization of the film by means of a physician's lecture, we find very few sources on the practice. In other words, the introductions which were given to the audience before the films' screenings have not made their way into the (film) archives. This may explain

1 von Keitz 2005, S. 287.

2 Tissé also shot the fictional sequences of the film. The documentary parts were shot by E. Berna. Efforts by Lazar Wechsler attempted to persuade Sergei Eisenstein to direct the film, but he turned down the offer. von Keitz 1999, 101. For the wider context of this film see also: Dumont 1987, 117-120; Albera 1976, 1993, 2002.

3 For an overview of the history of health education films see: Laukötter/Bonah 2009,121-145. Laukötter 2015. 
why so little has been written on this common practice. ${ }^{4} \mathrm{I}$ argue that an analysis of these under-investigated lectures can raise new stimulating epistemological questions on the historical status of health education films, as these lectures changed the filmic dispositive. ${ }^{5}$

\section{Situating Frauennot-Frauenglück in the landscape of German health education film}

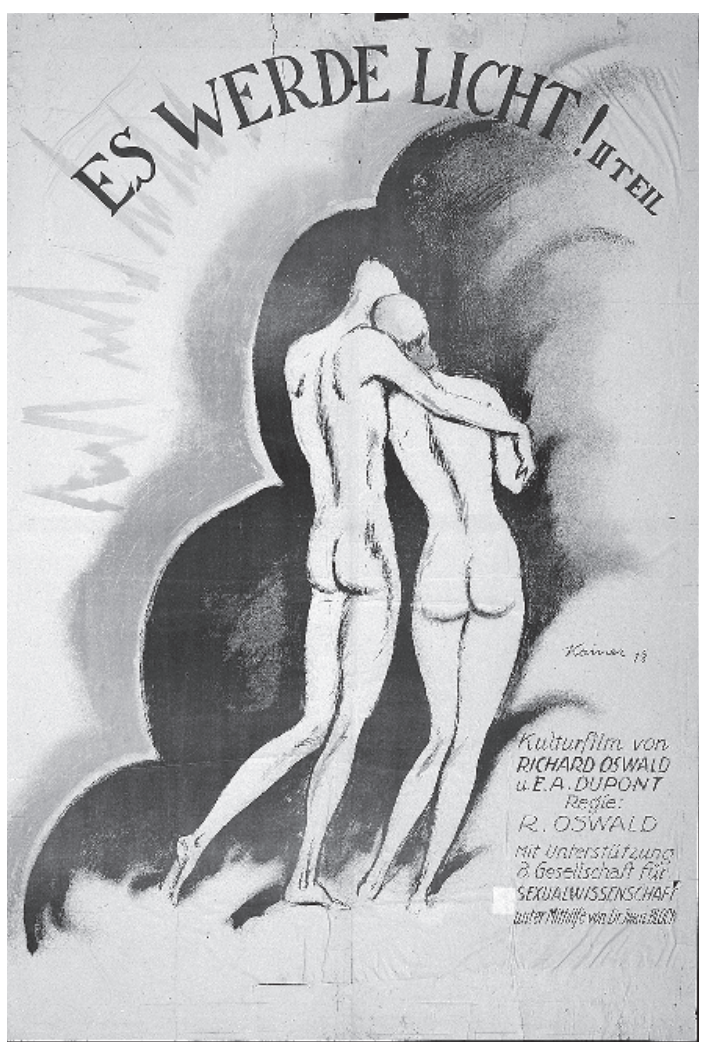

The history of sexual health education films in Germany starts with a feature film. In the midst of World War I, and in cooperation with the influential German Society for the Struggle Against Venereal Disease, the Austrian director Richard Oswald directed the film Es Werde Licht! in 1916/17 - a sibling-drama about a young, permissive, pleasure-seeking artist suffering from syphilis, who infected his brother's bride because of his careless attitude towards the disease. $^{6}$

Image I: Es Werde Licht! Provoking debates on sex education.

This film was first shown in Berlin in 1917 and was a great success with audiences, resulting in a sequel released: Es Werde Licht! (second part in 1917/18; a third part in 1918 and a fourth in 1918 by the name of Sündige Mütter (Sinful Mother). At the same time, the film can be identified as a starting point of a discourse - lasting throughout the Weimar period - on the

4 Ursula von Keitz quotes the lecture by Peter Schmid in her book briefly.

5 The concept of the film dispositive takes into account that not only the film itself but the whole film setting (the space of its screening, the placement of the audience, technique filmic developments, cultural traditions and so on) has an impact of the film. It can be described as efforts to link film and audience. See: Foucault 1978; Baudry 1980; Reichert 2007; Albera/Tortajada 2010.

6 See for his biography: Goergen, 2005, 247-316 and Kasten/Loacker 2005. 
visibility of bodies, sexual attitudes, orientations and practices in films and more general on the use of film in society. From the very beginning, Es Werde Licht! split the audience. On the one hand, euphoric reviewers lavished praise like "no brochure, no lecture can teach as effectively as this great artistic film in five acts by Richard Oswald." $\mathrm{O}$ On the other hand, critics argued that Oswald was driven by economic motives. The motivation behind his use of so-called lascivious scenes to attract mass audiences was judged to be flagrantly self-serving. Oswald was even accused of increasing venereal disease because his film encouraged the idea of extramarital sexual intercourse. ${ }^{8}$ While Oswald classified his film as "a work of social hygiene", his opponents classified his films by labelling them not as sex education films, but rather as films of sexual incitement ("sexuelle Animierfilme"). ${ }^{9} \mathrm{He}$ was also accused of disguising sexually stimulating films as scientific works. The national assembly even lambasted Oswald's films as a "Kinopest" (cinematic plague). ${ }^{10}$ In 1919, Oswald finally responded to these accusations, saying "I reject the bogus claim that I have ever used the label of 'sex education' as a cover for obscene films. Moreover, I will take legal action against anyone who makes such claims in the future."11

It was Oswald's films in particular that spurred the debate on censorship and that finally led to the establishment of a censorship regime in May 1920. This visual regime censored every film before it was released. On ethical grounds, so-called "delicate" scenes were cut, misleading titles were changed, and audiences were restricted by age or sex.

Because of this ongoing debate, the German Society for the Struggle Against Venereal Disease ceased its cooperation with Oswald, no longer working with him on the advanced serialisation of these films. Instead, the society began to cooperate with Curt Thomalla and Nicholas Kaufmann, two physicians who had been involved in the establishment of the Medical Department in the Universal Film Aktiengesellschaft (UFA). In this department, a huge variety of films with health education topics were produced within a few years. Thomalla and Kaufmann were also involved in many of these productions, in several different capacities. Thus both had been part of 1919/20's Krüppelnot-Krüppelhilfe (The Misery and Salvation of a Cripple), the first so-called UFA Kulturfilm - a film which introduced the Oskar-

7 Bundesarchiv Berlin R1501: 126313.

8 Ebd.

9 Ebd. On this debate see for example: 26 June 1920.

10 Edb. Stenographischer Bericht der Nationalversammlung, 101. Sitzung, Freitag, 17. Oktober 1919.

11 Filmkurier, 3 July 1919. 
Helene-Heim, an orthopaedic clinic, to illustrate how modern medicine treats physically disabled people. ${ }^{12}$ In cooperation with the German Society for the Struggle Against Venereal Disease, Thomalla and Kaufmann worked on their first sex education film in 1919, providing the script for the film Geschlechtskrankheiten und ihre Folgen (Sexual Diseases and their Consequences). ${ }^{13}$ This film, which took an explicitly didactic and documentary stance, was first released in Berlin and then shown for several weeks in thirteen cities and in small villages across Germany. ${ }^{14}$ The film also found an audience abroad in places like the US and Japan. ${ }^{15}$ The film was very well attended thanks to low ticket prices and promotional tickets. Screenings were preceded by a mandatory introductory lecture on venereal disease. The film explains in details the diseases of gonorrhoea and syphilis and their origins, showing the progression of the diseases using drawings or diseased bodies. The film also elaborates on the means used to combat and cure the diseases, including information about the doctors who discovered it and the drugs used to cure it. Because the film was produced before the implementation of censorship in 1920, it was first censored only a year later. Thereafter, the film could be shown to adolescents only if the audience was segregated by gender. The film received favourable reviews and the film journal Der Kinematograph praised its persuasiveness. ${ }^{16}$ Other scientifically- and pedagogically-oriented films were released, such as 1922s Steinachs Forschungen (Steinach's Research) ${ }^{17}$ and Hygiene der Ehe (Matrimonial Hygiene) or Geschlechtskrankheiten und ihre Bekämpfung (Sexual Diseases and the Measures Taken Against Them) from 1923/24, a film which was released in two versions - for female and male audiences. Geissel der Menschheit (Scourge of Mankind), another 1926 film on syphilis by Thomalla and Kaufmann, also belongs to this group of early health education films.

As instructive, informative and scientific as these educational health films may have been, new and unconventional discussions of topics such as abortion, prostitution, reproduction and (homo)sexuality found a home in feature films. Early such releases include a series by the director Georg Jacoby, Keimendes Leben (Germinating Life) ${ }^{18}$ or Arme Kleine Eva (Poor Little Eva)

12 Kreimeier, 2005; Laukoetter 2010; Osten 2009.

13 Kreimeier 2005, 67-86.

14 Ellenbrand 1999, 170f.

15 Mitteilungen der Deutschen Gesellschaft zur Bekämpfung der Geschlechtskrankheiten (1922), 142.

16 Der Kinematograph, März 1920.

17 Zimmer 2007.

18 Two parts, 1918; Moral und Sinnlichkeit (third part of Keimendes Leben, 1919). 
(various directors) ${ }_{19}^{19}$ Richard Oswald's two-part Prostitution ${ }^{20}$ and individual films like Anders als die Anderen (Different from the Others) of 1919, 1925's Frauen, Hütet eure Mutterschaft (Women, Tend to your Motherhood) and Tagebuch einer Verlorenen (Diary of a Lost One) in 1929. Contemporary gender roles were questioned and widely discussed throughout the Weimar period, in films like 1924's Muss die Frau Mutter Werden? (Must the Woman Become a Mother?) ${ }^{21}$ and Kreuzzug des Weibes (The Wife's Crusade) from 1926, ${ }^{22}$ Kinderseelen Klagen Euch an (Children's Souls are Accusing You) produced in 1926/1927, and Geschlecht in Fesseln (Sex in Chains) of 1928. ${ }^{23}$ An in-depth analysis of what is novel and what is more traditional in this corpus of work would be useful, as these films provide not only insights into new conceptual developments but can also be read as providing new performative scripts on how to live according to these new conceptions. ${ }^{24}$ I do not pursue this avenue of research within the purview of this paper, preferring instead to emphasize the impact of these films on the cinematic landscape and their effect on the emerging field of health education.

Image II: Wege zur Kraft und Schönheit. Dancing Nudity as a new form of body culture.

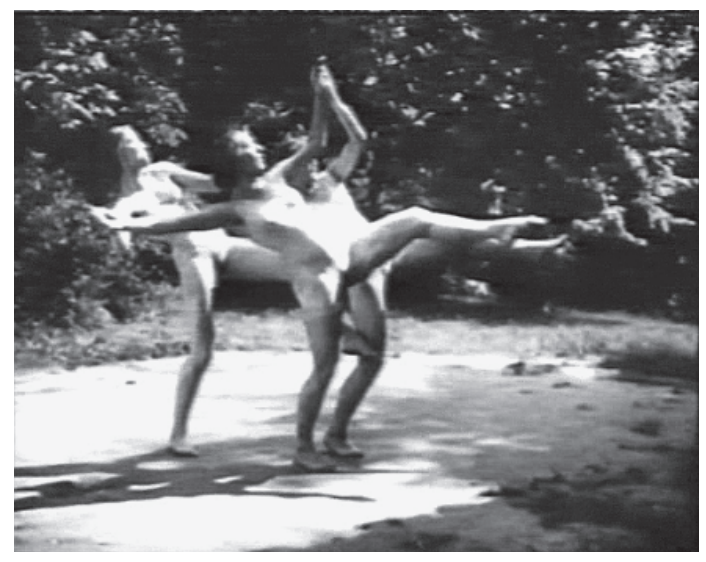

One of the first harbingers of this change is 1925's Wege zur Kraft und Schönheit (Ways to Strength and Beauty) directed by Nicholas Kaufmann and Wilhelm Prager. This film leaves the purely didactic tendencies of earlier

19 First part of the film, 1918; second part 1921, third part 1931.

20 The first part was called Das gelbe Haus, 1918/19, the second part was called Die sich verkaufen, 1919.

21 Frauen, hütet eure Mutterschaft! (changed version of Muss die Frau Mutter werden?) (1925, lost).

22 This anti-abortion film Kreuzzug des Weibes was first released in 1926. It was remade for the American audience as Unwelcome Children in 1928. Von Keitz 2000.

23 The following films are also part of this corpus: Frauenarzt Dr. Schäfer (1928), Der Sittenrichter (\$ 218). Eine wahre Begebenheit (1929), Madame Lu, die Frau für discrete Beratung (1929), Cyancali (\$ 218) (1930). See von Keitz 2005, 387f who provided the first overview on these films.

24 Sauerteig 2010; Simon/Gagnon 1986. 
health education films behind, deciding not to use disease as an argument, favouring instead idealised body culture (see image II). It is again Nicholas Kaufmann who provided the script, and he also worked as scientific advisor on the film. ${ }^{25}$ We can read the health education film Falsche Scham (False Shame) - directed by Rudolf Biebrach and produced with the scientific advice of Curt Thomalla und Nicholas Kaufmann in 1925/26 - along similar lines. ${ }^{26}$ The film relies on an episodic structure to narrate various consequences of a syphilis infection: two students who become acquainted with a prostitute, a medical student who becomes aware of his syphilis infection, an infected nurse who transmits the disease to a baby, and a naïve young woman who becomes acquainted with a careless infected young man. Although many scenes from Geissel der Menschheit were reused in Falsche Scham, and even though a physician plays an important and decisive role in all of these stories, the instructional character of his advice is not foregrounded. ${ }^{27}$ In that sense, Falsche Scham marks a transition in the narration of health education films. (See paper by Joël Danet).

Interestingly, Falsche Scham and the Richard Oswald film Dürfen Wir Schweigen? (Should We Keep Silent?) from 1925/26 - a remake of the first part of his previous production Es Werde Licht! - were the only films which were shown at the Imperial Health Week ("Reichsgesundheitswoche") in April 1926. ${ }^{28}$ The Imperial Commission on Public Hygiene and Education had requested that Richard Oswald presents this film. This invitation suggests that by the mid-1920s, the lines between fictional and instructional films and between entertainment and educational films were blurred both in terms of production and reception. ${ }^{29}$

Health education films were produced along these lines in the following years. Examples include 1931's Feind im Blut (Enemy in the Blood) and Frauennot-Frauenglück.

25 This film was - in terms of its reception - the most successful UFA production among the films classified as Kulturfilm ("cultural film"). For the impact of this film see: Müller 2005, 76-95;

26 From 1926 onwards Rudolf Biebrach was responsible for the UFA's acting school.

27 Kreimeier 2005 (Komplex-starr), 94f.

28 The Imperial Health Week lasted from the $18^{\text {th }}$ to $24^{\text {th }}$ of April 1926. A variety of media were used to enhance awareness of pub. Besides exhibitions and lectures also two films were shown nationwide.

29 Even though contemporaries as Curt Thomalla insisted on the distinction and on his right to discuss medical problems using the medium of film. In April 1926 he wrote: "If it had been Mr. Oswald's aim to recount such a real-life scenario and its full-blown consequences, then the main character would have to have been a paralytic or syphilitic person. For that is the fate generally awaiting those suffering from venereal disease [... ] It is typical of this kind of film that the word 'syphilis' is meticulously avoided in every frame." See: Filmkurier, 9 April 1926. 
Opening with statistical information on abortion and childbirth, FrauennotFrauenglück tells the fates of three women in interwoven fictional sequences: a poor woman who is about to get her fifth child, and who decides to perform an abortion with the help of a charlatan; a well-off young woman who makes acquaintance with a man in a café, and who after hours of amusement (drinking alcohol and smoking cigarettes) ends up in a hotel, where she becomes pregnant by the young man; and finally a young working-class woman married to a crane driver, who gladly tells her partner that they expect a baby, before witnessing her partner's fatal accident. All three of these women, from socially different backgrounds, share the need to find a solution to their personal crises.

Image III: FrauennotFrauenglück. Pregnancy and poverty: the misery of a woman.

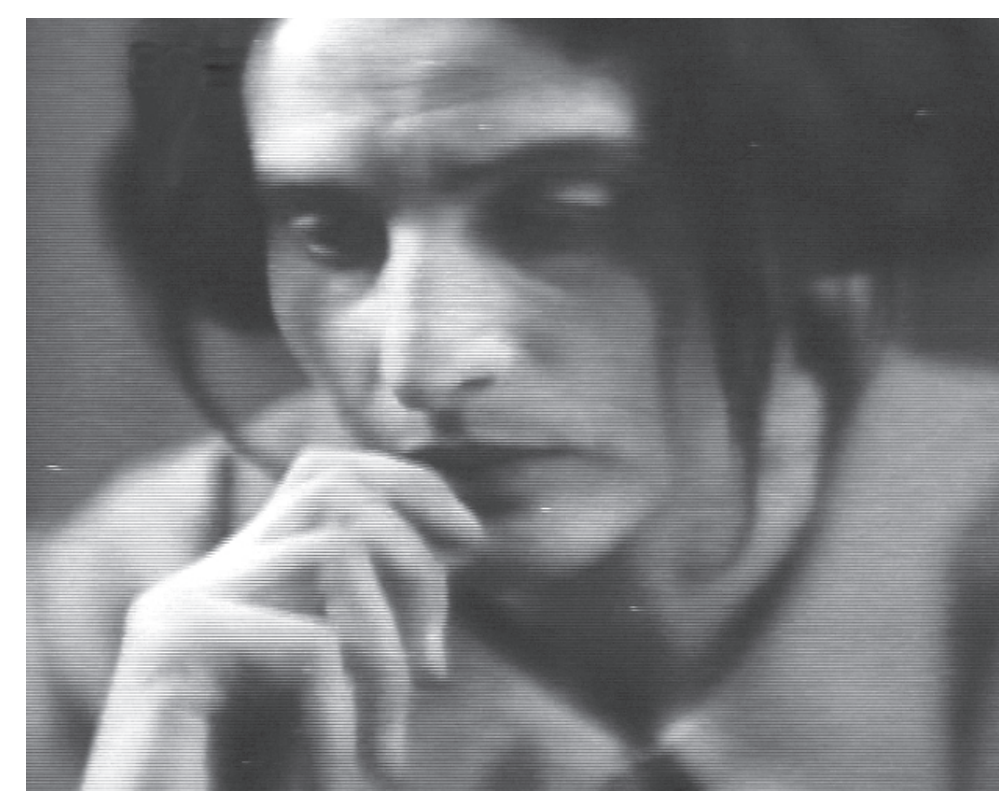

In interwoven documentary sequences shot by Emil Berna at the gynaecological university hospital in Zurich, scientific or medical answers to problems like these are shown: the almost fatal end of the woman who receives an abortion from the charlatan is helped with an immediate blood transfer in the hospital (see image $\mathrm{V}$ ), and caesarean sections are performed in case of anticipated problems during childbirth.

Falsche Scham and Frauennot-Frauenglück introduce and combine several problematic individual life stories, which are solved by "answers" in the form of medical expertise and practice. Their key concern is to promote medicalization. In subsequent years, this narrative structure was further explored, to the extent that it can be regarded as a distinguishing feature of this era of health education film in Germany and beyond. 

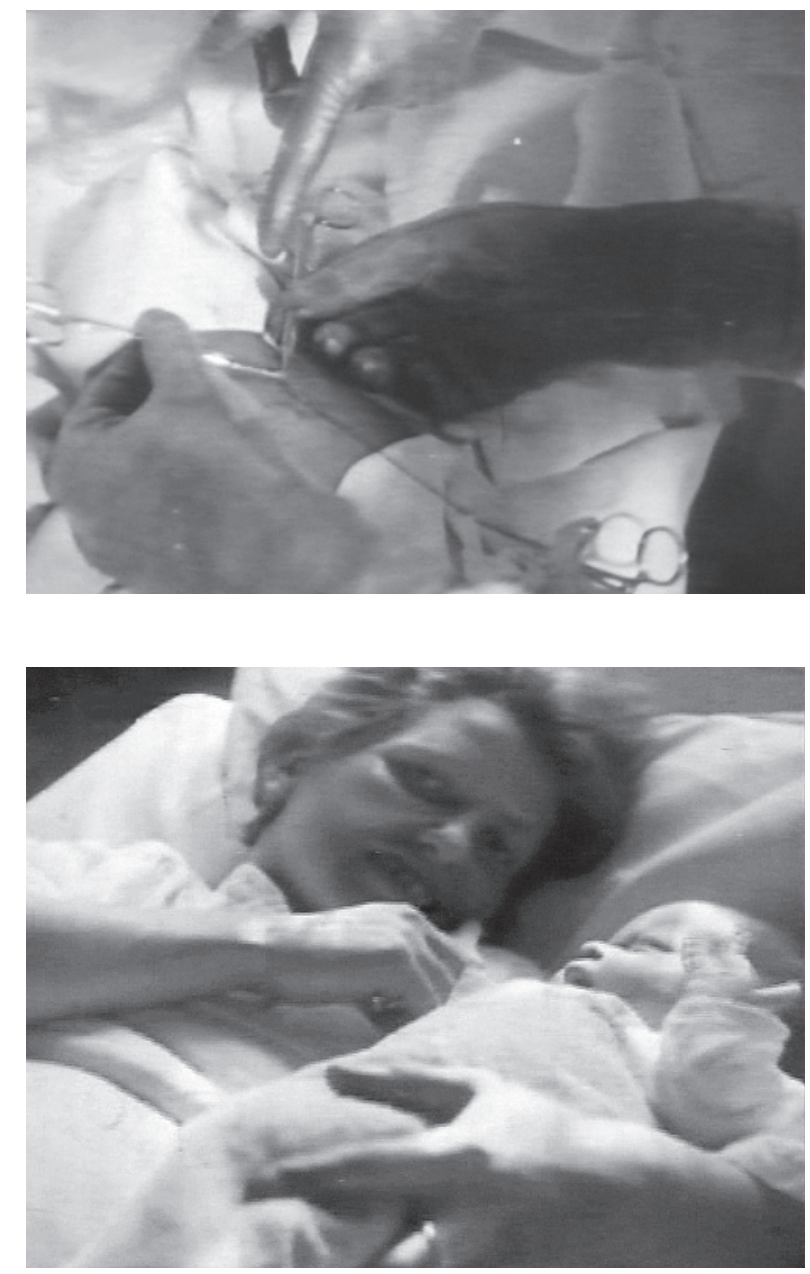

Image IV: Frauennot-Frauenglück. Blood transfusion presented as a medical technique of survival.

Image V: Frauennot-Frauenglück. After a caesarean section: the joy of motherhood.

This may be one reason why Frauennot-Frauenglück (alongside other health education films of the time) circulated beyond national boundaries. Still, the film's transnational circulation and the variety of versions and languages which travelled throughout the world is exceptional. The film was released in three languages: in German as Frauennot-Frauenglück, in French as Misère et fortune de la femme, in Italian as Miseria e felicita della donna. ${ }^{30}$ It seems that Tissé even produced a Spanish version called Natalidad while he was working in Mexico in 1938. ${ }^{31}$ The film was also shown in Austria and in an adapted silent version for French audiences under the title L'appel de la vie. In 1937/38, attempts by the producer Lazar Wechsler to reissue the films in France with new footage under the new title Le droit à la vie failed

30 von Keitz 1999, 101.

31 von Keitz 1999, 103. Moreover there are clear indications that English translations (Misery and Fortune of Women for Great Britian and Women's Misery - Women's Happiness for the US) and a Brazilian version (Miséria e Fortuna de uma Mulher) exist. The production year of all of these films is unclear. I thank Christian Bonah for alerting me to the existence of these films. 
because of French censorship. ${ }^{32}$ Furthermore, the film itself marks the transition from silent to sound film as a variety of different versions of the film exist, both with and without sound. Frauennot-Frauenglück's complex historical circumstances indicate that the first version was shot as a silent film and that sound was added later. ${ }^{33}$

The silent German version was shown in Austria, but in Switzerland, where it was produced, it took only ten days for the police department in Zurich to ban screenings of the film. In Germany, the film had its premiere three months after its world premiere (and after several demands from the censorship board to change scenes) on the $20^{\text {th }}$ of June 1930, in Berlin's Atrium theatre.

While such material was routinely featured in so-called teaching films shown exclusively to physicians and medical students in hospitals and universities for training purposes (showing caesarean sections, blood transfusion or other medical activities during childbirth), it was far more uncommon in health education films addressed to a wider public. This new visibility was one of the reasons that the film sparked several controversies. ${ }^{34}$ While a number of scenes were cut in various countries, in Germany, heated debates even led to local authorities, for instance in Munich, to require further censorship..$^{35}$ Consequently, a variety of versions of this film can be found in the archives. These acts of censorship indicate that these versions might, for example, differ in terms of scenes (excluded, inserted), chronology, subtitles (excluded, inserted) and the use or non-use of sound, and that all of these interventions might change the narrative of the film substantially. Therefore, as in other cases in the history of health education, claiming that there is one definite version of Frauennot-Frauenglück would be factually inaccurate. ${ }^{36}$

Beyond the censorship of different scenes within the film, the censorship board demanded an introductory lecture by a physician before screenings.

Having shown that controversies and censorship gave a new visibility to health education films, I will now go on to document how these introductory lectures contributing to shaping this new visibility through different means.

32 Lefebvre 1996, p. 234-239.

33 von Keitz 2005, 285.

34 von Keitz 2005, 282.

35 In Southern Germany, various lobby groups unsuccessfully pressured the Bavarian Department of the Interior to ban the film. The Bavarian state also launched legal proceedings against the production company "Präsens Film". After two years of litigation the film was eventually banned in Munich. See von Keitz 2005, 295-296 and BayHStAMInn 72693.

36 Bonah/Cantor/Laukötter 2015. 


\section{The explication of Frauennot-Frauenglück: Health education films and the practice of the introductory lecture}

From the earliest days of film up until 1907/08 a period which Tom Gunning named the "time of cinema of attractions" - the presence of a person who commented, explained, interpreted or even redefined the films was a typical part of the cinematic experience. Sometimes the speaker was accompanied by a piano music. These so-called "explainers" of the pictures were in charge of adjusting the expectations of the audience to the screened image. ${ }^{37}$ As the use of intertitles in films started in 1903, intertitles and explanatory lectures coexisted for a short time. However, after the First World War, the use of intertitles and the increasing narrative straightforwardness of the films gradually made it unnecessary to provide additional information. ${ }^{38}$ Thus, for films in general, "explainers" were phased out in the West after World War I. Yet, this was not the case for health education films.

As mentioned above, introductory "scientific lectures" were the rule rather than the exception in Weimar-era health education films. In sources on censorship and in reports about the films' screenings in newspapers and magazines, we find extensive evidence suggesting that they were a common practice. Their intent was clear: the lectures were meant to increase awareness of the issues raised in the film and make it more easily accepted. Yet, very few sources offer insights into the development of this practice. The length, form and content of these lectures remain matters of debate.

The two lectures which accompanied Frauennot-Frauenglück might not be representative of the genre as a whole, but they can provide new insights into at least some of these questions. That said, these rich sources have their limitations. They do not tell us about the presentation of the lectures in practice (side notes, emphasis, gestures, omissions, additionally used material etc.) or about their effects on audiences and how they might have changed perceptions of the film.

In general, one can argue that this form of audience guidance has certain implications; for example, it transforms the meaning of the venues and of the films. Sometimes these health education films were shown in lecture halls, in schools, in city halls or as a part of a health exhibition, as in the case of Geschlechtskrankenheiten und ihre Bekämpfung and Falsche Scham. How-

37 In German it is the "Kinoerklärer", in French: conférencier. Leonhard 2001, 1110. Gunning 1990, 56-63; Elsässer 2002, 47-68, 69-93. 38 Horak. 
ever, these films were most often screened in movie theatres, as in the cases of Frauennot-Frauenglück, Falsche Scham und Feind im Blut. At a time when movie theatres became a part of urban space and moviegoing became a popular leisure activity, the social functions of movies were widely discussed. Contemporaries from the left and right such as Oswald Spengler, Martin Heidegger, Bertolt Brecht, Siegfried Kracauer and Walter Benjamin discussed film's potential as a symptom of a new emerging modernity. In this context, the movie theatre was very often construed as a "place of distraction". ${ }^{39}$ Moreover, as outlined before, films such as those of Richard Oswald stimulated ideas about the movie theatre as a site of sexual arousal. Against this backdrop, a talk preceding a health education film has a specific function. The physician's lecture redefines the movie theatre as a space: from a space of "distraction" it becomes a space of learning - more akin to a school classroom or a university lecture. It also makes the exploitation side of the films politically acceptable by offering a token of scientific reliability.

Though they are not precisely dated, the lectures under consideration here probably date back to around $19300^{40}$ They are both about the same length: the first one has 1222 words, and the second one contains 938. The lectures might thus have lasted between ten to fifteen minutes. According to various censorship decisions the film itself was about $1680 \mathrm{~m}$ long - depending on how it was screened the film's running time must have been approximately 55 minutes. Together the lecture and the film must have taken up 65 to 70 minutes, not unlike a university lecture.

The first lecture was written by Nicholas Kaufmann, a central figure in both the production and development of these films. In his five-page-long talk, Kaufmann starts with a reference to contemporary debates on Frauennot-Frauenglück: whether it should be shown in a public theatre, and the "sexual problems" raised by the film. He remarks that movie theatres derived their popularity from their entertainment function. So-called sex-hygiene films had an exceptional position as they provided high-quality entertainment: as these films address issues ranging from disease to health, from life to death, they have to interest the entire spectrum of the potential audience members. To Kaufmann, Frauennot-Frauenglück addressed human procreation and birth as the most important issues in public health. Sensitive top-

39 Kracauer 1972.

40 In other sources, including censorship documents, where Peter Schmidt's lecture was mentioned are dating to 1930. Moreover it seems that Schmidt died in 1930. The lecture by Nicholas Kaufmann was found in the film archives of the "Bundesarchiv Berlin" it is added to a protocol from the 8th of November 1930 of the censorship by the "Film-Überprüfstelle": BArch, R 9346 / O 1016-2233. 
ics were depicted: care for pregnant women, birth control, abortion and hygienic birth proceedings. ${ }^{41}$ Still, he claims that all of the dangers related to unhygienic births and unprofessional abortions were addressed objectively. In his view, though even a professional abortion was risky in that it might cause "nervous" or "mental defects", an unprofessional abortion put the woman's life at risk. Besides these risks, the film outlined the dangers of "low morals" regarding birth regulation and birth control. According to Kaufmann, a film's function was not to take a stance in favour or against existing laws, but to show how these laws play out in people's lives. While the state had to protect children's rights (even before birth), women and men should act responsibly in order to avoid breaking the law. ${ }^{42}$ The film shows how to avoid these conflicts caused by negligent and careless copulation in a straightforward manner. Kaufmann would consider the film a successful if it managed to make at least some people refrain from indulging in irresponsible behaviour.

The second lecture, which is about as long as Kaufmann's, was given by the Berlin physician Peter Schmidt. Schmidt had worked together with his colleague Ludwig Levy-Lenz on experiments on rejuvenating surgery, a technique introduced by Eugen Steinach (and the subject of a separate film as mentioned before). ${ }^{43}$ Levy-Lenz himself was strongly involved in campaigns against venereal disease at that time ${ }^{44} \mathrm{He}$ had also established one of the first sexual outreach clinics ${ }^{45}$ and published the first scientific book on abortion in Germany in 1930.46

Considering all this, it is not altogether unsurprising that Schmidt's lecture displays a different approach. However, he begins by identifying the same conflict as Kaufmann: the state's interest in protecting the unborn and women's interest in protecting their own bodies. Yet for Schmidt, the problem is an international one: he refers to intense debates on legal acts in respect to abortion in "all civilised countries of the world" since World War I. ${ }^{47}$ $\mathrm{He}$ also cites several novels, theatrical plays and film dramas that dealt with this issue. He then criticizes the endless efforts to reform the law, which split physicians into two adverserial camps. In his opinion, the current laws should not be retained because they are constantly broken. He mentions Russia,

41 Kaufmann p. 2.

42 Kaufmann p. 4.

43 Schmidt 1921; Schmidt 1922.

44 Levy-Lenz 1919.

45 Levy-Lenz 1926.

46 Levy-Lenz/Bendix 1930.

47 Schmidt p.1. In Germany these legal acts are summarized in a relevant paragraph in the penal code: $§ 218$. 
where abortion was legal, and dismisses the German arguments against legalised abortion in Russia as propaganda. Interestingly, Schmidt explicitly mentions that the point of his lecture is not to promote his own opinion but rather to come up with a remedy to the increasing "sexual misery" (Sexualnot) and the danger faced by woman. While it was clear to him that nobody could force a woman to keep the unborn baby in an emergency, he thought that these women needed to know how dangerous unprofessional help is. The masses also needed to be informed about birth control. Thus, to Schmidt, the film only addressed part of the problem: it shows the dangers of an unprofessional abortion and how the woman narrowly escapes death by receiving medical attention in the clinic. (He also noted a fact left unsaid in film: the hospital had no obligation to report a criminal abortion. Women received help in the clinic without any prior investigation of the circumstances that brought them there).$^{48}$ Consequently, and again in contrast to Kaufmann, Schmidt outlined what is missing in the film. He considered abortion be wrong because it is an intervention in the life of the mother and affects her whole body, and advocated prioritizing education on contraception. He referred to England, where because of the movement to promote birth control, women of all classes received training on preventing pregnancy. The rationale was to have fewer, but healthier and happier children. He also connected this with contemporary medical science innovations in contraception. ${ }^{49}$ While Schmidt saw the possibility of separating the consequences of love and the pleasure of the act as a significant cultural achievement, he argued that in the current state of birth control techniques, the masses needed to know about the dangers of unprofessional abortions. In his view, the film's greatest achievement was to show the layperson how organised and hygienic operation rooms were, as it was there that abortions should take place. $\mathrm{He}$ concluded by praising the controversial operation scenes as objective and dauntless. ${ }^{50}$

There are obvious differences in form and content between the two lectures. It seems that Kaufmann identified his role as akin to (what he saw in) a film like Frauennot-Frauenglück: He did not position himself against statements of the film. On the other hand, Kaufmann concurred with the film he introduced in emphasizing the dangers of careless sexual behaviour and unprofessional abortions. However, unlike the film, he did not praise the efforts and the successes of medical professionals. Moreover, and in contrast to

48 Schmidt p. 2

49 Schmidt p. 3

50 Schmidt p. 4. 
Schmidt, Kaufmann also neglected to provide any further information, context or related developments pertaining to the film's topic. Overall, Kaufmann focused on creating tension and raising awareness by pointing to a number of issues and dangers before the screening. Stressing the potentially fatal consequences of an unprofessional abortion seemed to him the best and most effective preparation for the audience. These problems are serious, we can imagine him saying, and that is why you have to watch and listen.

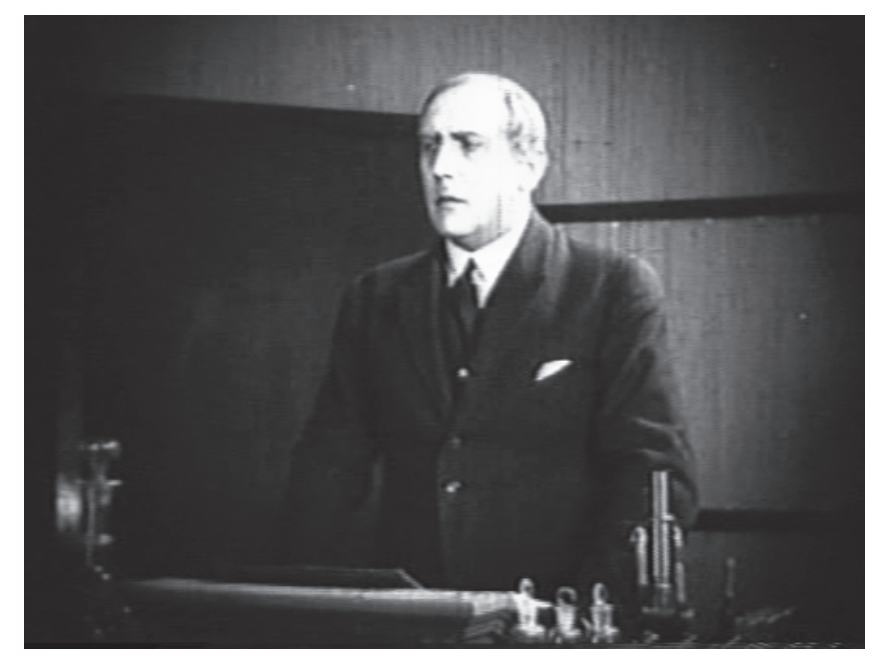

Image VI: Falsche Scham. The physician as lecturer and advicegiver in the film.

As mentioned before, physicians play an important part in health education films such as Frauennot-Frauenglück: they provide not only a cure but also advice to their patients. Sometimes, as in the case of Hygiene der Ehe or Falsche Scham (see image VI), physicians are even shown giving a lecture to an audience of students or other groups in the film itself. In such cases the introductory lecture - like Kaufmann's - replicates the function of the advicegiver and in doing so reinforces the physician's status: it links the film with the physician who represents a medical authority. Thus the film's intellectual origin is the medical science as a prototype of seriousness (and not of amusement as films by Richard Oswald stand for). In other words, the physician functions both as a guarantee of the film's social acceptability and as a promoter of medicine.

In contrast to Kaufmann, Peter Schmidt used the lecture to point out the wider context in which the problem should be understood. Drawing on other media (including films) that addressed the same issue, he linked FrauennotFrauenglück to feature films as outlined in the first part of this article. $\mathrm{He}$ mentioned international developments in order to highlight his expertise. References to Russia and England supported his own arguments, which 
differed from the film's narrative, allowing him to discuss the legalisation of abortion and birth control techniques. That he criticized the film's decision to show only a part of the problem reflects Schmidt's ideas on what an introductory lecture should be. Unlike for Kaufmann, to him the lecture was not about preparing the audience for the screening, but instead a chance to voice his social(ist) views on abortion and contraception. His comments on the fact that hospitals did not attempt to ensure prosecution in the case of criminal abortions further reflect his socio-political intentions. These positions can be connected with Eduard Tissé's (and socialist avant-garde filmmaker Sergej Eisenstein's) interest in making Frauennot-Frauenglück as a social agitation film.

Schmidt's critique of contemporary regulation with respect to the penal code (the paragraph 218) caused much controversy. After several previous efforts, the Bavarian ministry of the Interior (together with the states of Baden and Thüringen) filed a petition to impose a ban Frauennot-Frauenglück. Peter Schmidt's lecture was cited in their argument against the film: the petitioner called it "superficial," "unclear" and "confusing." ${ }^{51}$ Even though the FilmOberprüfstelle (Supreme Board of Film Classification) ruled against a ban on the $22^{\text {nd }}$ December 1930, it conceded that Peter Schmidt's lecture was incompatible with the film. The board went even further and argued that this lecture would "severely hinder" the film from achieving its goal. ${ }^{52}$ The lecture was therefore prohibited and the board decided that from that point on, Frauennot-Frauenglück could be screened without an introductory talk. Although the lecture by Schmidt was prohibited the decision of the censorship board shows clearly that this lecture was not only associated with the film but that these different techniques were both object of their decision. As such the film and the lecture can be regarded as a whole unit.

\section{Conclusion}

In this article I have documented the evolution of interest in sexual health education films in the early decades of the twentieth Century and the transformations of their narratives resulting from the expansion of feature films in the Weimar-era. Frauennot-Frauenglück's history illustrates a number of developments in this field. Looking at the amount of films produced in a very short time span, one might draw the conclusion that these films were not only 
a new but also a quite successful public education medium. Yet, the common practice of accompanying these films with lectures, which I analyzed in the second part of the paper, might lead us to qualify the potential of this new media technique: even though the two lectures differ in various aspects, both underline the film's connection to language - to the spoken and written word. The practice of including introductory lectures as well as (in many cases) subtitles reflects the prevailing view that images were not selfexplanatory, and required additional words to work as educational tools. In that sense, the practice of lecturing can be regarded as a necessary technique: as a technique of rhetorical reworking of the film.

The two lectures under consideration here exemplify two different forms of rhetorical reworking: Nicholas Kaufmann's lecture is an example of rhetorical reworking relying on repetition and emphasis on specific aspects of a problem. In that line the lectures hinder that these films were forbidden. In other words: The use of these techniques made it possible for controversial films to be screened to the public by compromising with censorship.

As Peter Schmidt's lecture displays an approach consisting in providing additional context and information serving as the platform for the lecturer to air his own ideas, hence subverting censorship.

Whatever type these complementary talks might have represented, it seems fair to say that they endeavour to adjust or orient the visuality of what can or should be seen - in the interest of censorship boards or even against it. Moreover, as the first part of the article has shown and as various censorship decisions (ranging from requiring an introductory talk to its prohibition, and from an approval of a certain talk to that talk's prohibition) indicate: it was still under debate how a socially acceptable visuality should look like and how this rhetorical reworking should subsidiary work.

Even though we have (almost) no evidence on how these talks changed audience responses, it seems fair to say that they changed the filmic dispositive in a substantial way. It was no longer on the basis of the film alone that it was established which issues about sexuality could be publically screened and which were genuinely admissible. The censorship board's decision showed that the film and the lecture were regarded as a single entity.

Ultimately, the main contribution of this article has been to show that if we want to understand how these films provide new performative scripts of how to live, reflections on the epistemological status of health education films should take into consideration not only the films themselves, but their entire presentation including the introductory lectures. 


\section{Filmography}

Es werde Licht! (Germany, first part, 1916/17; second part 1917/18; third part 1918 - all are lost) Sündige Mütter (Germany, fourth part: Es werde Licht!, 1918, lost)

Keimendes Leben (Germany, two parts, 1918); Moral und Sinnlichkeit (Germany, third part of Keimendes Leben, lost)

Arme kleine Eva (Germany, 1918); Arme, kleine Eva (Germany, second part) (1921, lost); Arme kleine Eva (Germany, 1931, lost)

Prostitution. First part: Das gelbe Haus (Germany, 1918/19); Prostitution. Second part: Die sich verkaufen (Germany, 1919) (both lost)

Geschlechtskrankheiten und ihre Folgen (Germany, 1919)

Anders als die Anderen (Germany, 1919)

Krüppelnot-Krüppelhilfe (Germany, 1919/20)

Steinachs Forschungen (Germany, 1922)

Mu $\beta$ die Frau Mutter werden? (Germany, 1924, lost) Frauen, hütet eure Mutterschaft! (changed version of: Muß die Frau Mutter werden?) (Germany, 1925, lost)

Wege zur Kraft und Schönheit (Germany, 1924/25)

Dürfen wir schweigen? (Germany, 1925/26)

Kreuzzug des Weibes (Germany, 1926)

Geissel der Menschheit (Germany, 1926)

Geschlechtskrankheiten und ihre Bekämpfung (Germany, 1926)

Falsche Scham (Germany, 1926)

Kinderseelen klagen euch an (Germany, 1926/7)

Frauenarzt Dr. Schäfer (Germany, 1928, lost)

Geschlecht in Fesseln (Germany, 1928)

Der Sittenrichter (\$ 218). Eine wahre Begebenheit (Germany, 1929, lost)

Tagebuch einer Verlorenen (Germany, 1929)

Madame Lu, die Frau für discrete Beratung (Germany, 1929)

Cyankali (\$218) (Germany, 1930)

Frauennot-Frauenglück (CH, 1930)

Feind im Blut $(\mathrm{CH}, 1931)$

\section{Bibliography}

Baudry, Jean-Louis, "Le Dispositif. Approches métapsychologiques de l'impression de réalité", in: Theresa Hak/Kyung Cha (eds.), Apparatus (New York 1980)

Albera, François/Maria Tortajada (eds), Cinema Beyond Film. Media Epistemology in the Modern Era (Amsterdam 2010)

Albera, François, "Eisenstein en Suisse", Travelling/Documents de la Cinémathèque suisse (Lausanne 1976)

Albera, François, Un destin mouvementé: "Frauennot-Frauenglück”, in: Rémy Pithon (ed.), Cinéma suisse muet. Lumières et ombres (Lausanne 2002) 73-84

Albera, François, "L'Appel de la vie" [Frauennot-Frauenglück de Tissé-Eisenstein], in: Emmanuelle Toulet/Christian Belaygue (eds.), CinéMémoire. $3^{e}$ festival international. Films retrouvés - Films restaurés (Paris 1993) 92-99 
Bonah, Christian/Anja Laukötter, "Moving Pictures and Medicine in the First Half of the $20^{\text {th }}$ Century. Some Notes on International Historical Developments and the Potential of Medical Film Research", Gesnerus 66 (2009) 121-145

Bonah, Christian/David Cantor/Anja Laukötter, "Introduction”, in: Christian Bonah/ David Cantor/Anja Laukötter (eds.), Communicating Good Health (forthcoming)

Brecht, Christine/Sybilla Nikolow, "Displaying the Invisible. 'Volkskrankheiten' on Exhibition in Imperial Germany", Studies in History and Philosophy of Biological and Biomedical Sciences 31 (2000) 511-530

Dumont, Hervé, Histoire du cinéma suisse 1896-1965 (Lausanne 1987)

Ellenbrand, Petra, Die Volksbewegung und Volksaufklärung gegen Geschlechtskrankheiten im Kaiserreich und Weimarer Republik (Weimar 1999)

Elsässer, Thomas, Filmgeschichte und frühes Kino. Archäologie eines Medienwandels (München 2002) 47-68, 69-93

Foucault, Michel, Dispositive der Macht. Über Sexualität, Wissen und Wahrheit (Berlin 1978)

Goergen, Jeanpaul, "Ein ganzer Kerl. Richard Oswald im Spiegel der Kritik 19141929", in: Jürgen Kasten/Armin Loacker (Hg.), Richard Oswald. Kino zwischen Spektakel, Aufklärung und Unterhaltung (Wien 2005) 247-316

Gunning, Tom, "The Cinema of Attractions. Early film, its spectator and the AvantGarde", in: Thomas Elsaesser (Hg.), Early cinema. Space, frame, narrative (London 1990) 56-63

Hoffmann, Kay, “Zwischen Bildung, Propaganda \& Filmischer Avantgarde. Der Kulturfilm im internationalen Vergleich", in: Ramon Reichert (Hg.), Kulturfilm im $\langle$ Dritten Reich〉 (Wien 2006) 15-27

Horak, Hans-Christopher, "Filmerklärer/Filmerzähler", in: http://filmlexikon.uni-kiel. de/index.php? action=lexikon\&tag $=$ det\&id $=2734$

Jung,Uli/Martin Loiperdinger (Hg.), Geschichte des dokumentarischen Films in Deutschland. Band 1: Kaiserreich 1895-1918 (Ditzingen 2005)

Kasten, Jürgen, "Dramatische Instinkte und das Spektakel der Aufklärung. Richard Oswalds Filme der 10er Jahre", in: Jürgen Kasten/Armin Loacker (Hg.), Richard Oswald. Kino zwischen Spektakel, Aufklärung und Unterhaltung (Wien 2005) 15140

Kasten, Jürgen/Armin Loacker (Hg.): Richard Oswald. Kino zwischen Spektakel, Aufklärung und Unterhaltung (Wien 2005)

Kracauer, Siegfried, "Kult der Zerstreuung. Über die Berliner Lichtspielhäuser, 1926", in: Karsten Witte (Hg.), Theorie des Kinos. Ideologiekritik der Traumfabrik (Frankfurt am Main 1972) 230-235

Kreimeier, Klaus, "Ein deutsches Paradigma. Die Kulturabteilung der Ufa", in: Klaus Kreimeier/Antje Ehmann/Jeanpaul Goergen (Hg.), Geschichte des dokumentarischen Films in Deutschland, Bd.2:Weimarer Republik, 1918-1933 (Stuttgart 2005) 67-86

Kreimeier, Klaus, "Komplex-starr. Semiologie des Kulturfilms”, in: Klaus Kreimeier/ Antje Ehmann/Jeanpaul Goergen (Hg.), Geschichte des dokumentarischen Films in Deutschland, Bd. 2: Weimarer Republik, 1918-1933 (Stuttgart 2005) 87-119

Kutner, R., "Die Bedeutung der Kinematographie für medizinische Forschung und Unterricht sowie für volkshygienische Belehrung", Zeitschrift für ärztliche Fortbildung 8 (1911) 249-251 
Laukötter, Anja, "Vom Ekel zur Empathie: Strategien der Wissensvermittlung im Sexualaufklärungsfilm im 20. Jahrhundert", in: Sybilla Nikolow (Hg.), «Erkenne Dich selbst!> Strategien der Sichtbarmachung im 20. Jahrhundert (Weimar 2015, in print)

Laukötter, Anja, “Anarchie der Zellen'. Geschichte und Medien der Krebsaufklärung in der ersten Hälfte des 20. Jahrhunderts", in: Zeithistorische Forschungen/Studies in Contemporary History (online edition) 7,1(2010) 55-74,URL: http:// www.zeithistorische-forschungen.de/16126041-Laukoetter-1-2010

Lefebvre, Thierry, Cinéma et discours hygiéniste (1890-1930), Thèse de l'Université de Paris III (Paris 1996)

Leonhard, Joachim-Felix, Medienwissenschaften: Ein Handbuch zur Entwicklung der Medien und Kommunikationsform (Berlin 2001)

Levy-Lenz, Ludwig/Magnus Hirschfeld (Hg.), Sexual-Katastrophen. Bilder aus dem modernen Geschlechts- und Eheleben (Leipzig 1926)

Levy-Lenz, Ludwig/Magnus Hirschfeld (Hg.), Wie schütze ich mich vor Geschlechtskrankheiten (Berlin 1919)

Levy-Lenz, Ludwig/Magnus Hirschfeld /Kurt Bendix (Hg.), Die Schwangerschaftsunterbrechung: ihre Voraussetzung und ihre Technik. Bedeutung, rechtliche Grundlage, Indikationen und Technik des indizierten Abortes in den ersten drei Schwangerschaftsmonaten. Ein kurzgefaßter Leitfaden für Ärzte und Studierende (Berlin 1930)

Lutz Sauerteig, “'Wie soll ich es nur anstellen, ohne etwas falsch zu machen?' Der Rat der Bravo in Sachen Sex in den sechiziger und siebziger Jahren", in: Peter-Paul Bänziger/Stefanie Duttweiler/Philipp Sarasin/Annika Wellmann (Hg.), Fragen Sie Dr. Sex! Ratgeberkommunikation und die mediale Konstruktion des Sexuellen (Berlin 2010) 123-158

Mitteilungen der Deutschen Gesellschaft zur Bekämpfung der Geschlechtskrankheiten (MDGBG) 20 (1922) 142

Müller, Corinna, Frühe deutsche Kinematographie. Formale, wirtschaftliche und kulturelle Entwicklungen (Stuttgart/Weimar 1994)

Müller, Dorit, “'Gegen die Überwucherung des abstrakten Denkens': Wissen und Unterhaltung im Kulturfilm der 1920er Jahre", Zeitschrift für Germanistik 1 (2005) 76-95

Osten, Philipp, "Emotion, Medizin und Volksbelehrung. Die Entstehung des 'deutschen Kulturfilms"”, Gesnerus 66 (2009) 67-102

Ramón Reichert, Im Kino der Humanwissenschaften. Studien zur Medialisierung wissenschaftlichen Wissens (Bielefeld 2007)

Sauerteig, Lutz, Krankheit, Sexualität, Gesellschaft. Geschlechtskrankheiten und Gesundheitspolitik in Deutschland im 19. und 20. Jahrhundert (Stuttgart 1999) 89-125

Schmidt, Peter, Das klinische Bild des Fleckfiebers bei der polnischen Bevölkerung im besetzten Gebiet (Berlin 1917)

Schmidt, Peter, Die Erfolge der Steinachbehandlung beim Menschen (Berlin 1921)

Schmidt, Peter, Nicht müde sein! Der Kampf gehen die Müdigkeit (Leipzig 1929)

Schmidt, Peter, Theorie und Praxis der Steinachschen Operation (Wien 1922)

Schmidt, Ulf, "Der Blick auf den Körper. Sozialhygienische Filme, Sexualaufklärung und Propaganda in der Weimarer Republik", in: Michael Hagener (Hg.), Geschlecht in Fesseln, Sexualität zwischen Aufklärung und Ausbeutung im Weimarer Kino 1918-1933 (München 2002) 23-46 
Simon, William/John H. Gagnon, "Sexual Scripts. Permanence and Change", Archive of Sexual Behavior 15, 2 (1986) 97-120

Thomalla, Curt, "Hygiene und soziale Medizin im Volksbelehrungsfilm", Zeitschrift für Medizinialbeamte 29 (1922) 589-610

Von Keitz, Ursula, "Eisenstein und die Welt. Schnitte mehrdimensional. Der Fall Frauennot-Frauenglück". In: Münchner Filmzentrum (Hg.), Eisenstein und die Welt. Arbeitsmaterialien zur Filmreihe 1.1.-18.3.1998 (München 1999) 99-104

Von Keitz, Ursula, "Lebenskrisen en gros. Richard Oswalds Filme der 20er Jahre", in: Jürgen Kasten/Armin Loacker (Hg.), Richard Oswald. Kino zwischen Spektakel, Aufklärung und Unterhaltung (Wien 2005) 151-246

Von Keitz, Ursula, Im Schatten des Gesetzes. Schwangerschaftskonflikt und Reproduktion im deutschsprachigen Film 1918-1933 (Marburg 2005)

Von Keitz, Ursula, "Sittenfilm zwischen Markt und Rechtspolitik: Martin Bergers Kreuzzug des Weibes und seine amerikanische Fassung Unwelcome Children", in: Malte Hagener/Jan Hans (Hg.), Geschlecht in Fesseln. Sexualität zwischen Aufklärung und Ausbeutung im Weimarer Kino 1918-1933 (München 2000) 139-154

Zimmer, Alexis, Der Steinach Film ou la restauration des identités sexuelles à l'épreuve de la caméra, Master de l'Université de Strasbourg (Strasbourg 2007)

\section{Images}

I: Copyright: Beta Film GmbH/Deutsche Kinemathek für Film und Fernsehen

II: Copyright: Friedrich-Wilhelm-Murnau-Stiftung

III-V: Copyright: Praesens-Film AG

VI: Copyright: Friedrich-Wilhelm-Murnau-Stiftung

\section{Archives}

Bundesarchiv Berlin (BArch) R1501 Nr. 126313; R 86943

Filmarchiv des Bundesarchivs (BArch): O 1016-2233

Bayerisches Hauptstaatsarchiv (BayHStA) Mlnn 72693

Deutsche Kinemathek Berlin

Journals: Der Kinematograph, Filmkurier; Illustrierter Film-Kurier (and research on several films mentioned in the text) 